\title{
Determination of Stimulating Factors of Wild Asian Elephant (Elephas maximus) Dispersal from the Kaeng Krachan National Park to Surrounding Land Use in Thailand
}

\author{
Luechai KROUTNOI ${ }^{1,3, *}$, Thavivongse SRIBURI ${ }^{2}$, \\ SaowaneeWIJITKOSUM ${ }^{3}$ and Kamol NUANYAI ${ }^{4}$
}

\author{
${ }^{1}$ Interdisciplinary Program of Environmental Science, Graduate School, Chulalongkorn University, \\ Bangkok 10330, Thailand \\ ${ }^{2}$ Managing Director, Chula Unisearch, Chulalongkorn University, Bangkok 10330, Thailand \\ ${ }^{3}$ Environmental Research Institute, Chulalongkorn University, Bangkok 10330, Thailand \\ ${ }^{4}$ Kaeng Krachan Natural Park, National Park, Wildlife and Plant Conservation Department, \\ Bangkok 10900, Thailand
}

("Corresponding author; e-mail: kluechai@chula.ac.th)

Received: 8 June 2017, Revised: 17 May 2018, Accepted: 30 June 2018

\begin{abstract}
Wild Asian elephant (Elephas maximus) disturbances are a major conservation concern in Thailand. Elephant dispersal was observed to identify factors that encouraged seasonal migration from the Kaeng Krachan National Park (KKNP), of 466.24 hectares across, into adjacent agricultural lands at the Pa Deng sub-district (PDS) in Phetchchaburi Province, Thailand. Land use patterns in 1975, 1992, 2002, and 2011 from satellite images taken by Landsat-5 TM, and community attitudes on the impacts of land disturbance, were analyzed. All village chiefs were concerned about future management for living with the increased numbers of elephants strolling in their lands expanding from the KKNP border. In 1975, the area was almost completely forested, but chronologically changed to agricultural and community area by $6.43,8.34$, and $7.35 \%$ for 1992,2002 , and 2011 , respectively. The area of bare land and natural water courses was found to be reformed to $8.86,3.46$, and $1.38 \%$, in 1992, 2002, and 2011, respectively. It was concluded that community and agricultural development encroached upon the bare lands and water courses of elephants, and latterly interrupted elephant trails by forest fragmentation. Six elephant trails were found to be aligned east/west across KKNP into surrounding water reservoirs and agricultural lands, at 170 to $380 \mathrm{~m}$ above mean sea level (AMSL), at a slope of less than $10 \%$, and within a radius of 100 $300 \mathrm{~m}$ from communities. Along those trails, data of line transects revealed indirect evidence, $70 \mathrm{dung}$ piles, 27 feeding signs, and 26 footprints. They were directed to major water resources, e.g., the Deng, Paloa, and Kralang reservoirs. It can be concluded that an important factor influencing the elephant dispersal were water sources located at the border of conserved forest; therefore, water development for elephants in KKNP was recommended, using local community-based natural resource management.
\end{abstract}

Keywords: Land use changes, Asian elephant (Elephas maximus), dispersal, sustainable forest management, disturbance

\section{Introduction}

Sustainable wildlife management needs decisions to be made regarding human-wildlife interactions bringing disturbance at various levels of impact caused by direct structural and behavioral effects, or mortality, and indirect wildlife habitat alteration, such as territorial shelter, available food [1], and water [2]. In Thailand, the increasing tension of wild Asian elephant (Elephas maximus) disturbances is a major 
http://wjst.wu.ac.th

concern of wildlife conservation and protection, due to the direct and indirect disturbances. Many studies have determined structural and behavioral factors that influenced both the incidences of disturbance [3-6] and the elephant management response [7-9]. Elephant dispersal from the Kaeng Krachan National Park (KKNP) into adjacent habitats, which are agricultural lands at Pa Deng sub-district (PDS) in Phetchchaburi Province, is a classic example of evidence disclosing wildlife behavior that causes problems for humans (e.g., safety, satisfaction, economics, and property).

KKNP is an important elephant habitat with 500 - 600 elephants [10], and was declared in 1981 to be one of four protected areas in the Kaeng Krachan Forest Complex (KKFC). It is a highly important landscape for conservation, designated as a biodiversity hotspot, and was listed as an ASEAN Heritage Site in 2005. KKNP is the largest national park in Thailand and covers an area of 466.24 hectares at the southern end of the Tenasserim range [1], stretching from part of the Taninthayi National Park of Myanmar. Also, it is one of the most biologically important ecosystems of the region. It represents the convergence of several distinctive temperate, tropical, and subtropical floristic regions: the Indo-Burma in the west, Malaysian (Sundaic) in the south, Sino-Himalayan in the north, and Indochinese in the east. This location potentially makes it the most significant biodiversity hotspot in Asia. It provides a significant habitat for wild elephants and has been classified as a regional wild elephant protected area by the International Union for Conservation of Nature (IUCN). In 1996, the conserved forest area was increased by governmental policy by moving communities from the highlands to the lowlands, consequently resulting in land use changes by expansion of residential areas into the vacant areas which formed the KKNP buffer zone. However, the populations of human and elephants are dynamically interacted, and influenced the agricultural land utilization and raised their competitive territory [11]. By human presence, the alterations of physical landform and the competitive uses of natural resources, in particular water courses [3-5], considerably affected ecological processes in the environment and particular ecosystems [2] which led to elephants ranging into new human settlements for cultivated food and water [11] in the PDS area.

The direct interaction between villagers in the PDS has been described. The alterations of humanelephant conflict (HEC) level became a major public and politic concern [11-13] in the PDS area, where crop-raiding by elephants was the main form of HEC around the area [14] and has recently has become a serious conservation problem, instigated from elephant-attack incidences [15-16]. The problem has been changed in impact level and spatial disturbance by socio-economic and environmental factors [3,9,11].

Sustainable management should replace the existing trial-based activities to implement continuous plans for HEC amelioration [9,11,23]. Many attempts, using various methods, have been applied to ameliorate HECs, ranging from traditional farm-based deterrence to the use of watchtowers, loud noises, fireworks, powerful electric lights, and installing chili grease or electric fences around farms. In January 2014, collaboration among the community of PDS, Thai military officers, KKPN staff, and the Wildlife Conservation Society (WCS) constructed a $50 \mathrm{~m}$ high semi-permanent fence in PDS. However, the construction of these fences may have large, and perhaps unintended, impacts on elephant behavior $[11,19,22]$. In general, sustainable management requires understanding of elephant dispersals in home ranges [9,11,23], strategies of elephant behaviors [11] for resource utilization [17] depending upon the behavioral ecology of individual elephant bulls, and policy on land use adoptions embracing large spacious areas over long periods of continuous actions [1]. Thus, human-elephant interrelationship must be quantified and hypothesized regarding fundamental required factors [11] that should be tested prior to decision-making on mitigation measures [18,20,21]. This study aimed to determine the humandimensional aspect on the wild Asian elephant disturbance, summarizing community responses and local community-based natural resource management that can be applied to this topic and to land use management of the PDS area interrelated to KKNP conservation. 


\section{Materials and methods}

\section{Study area}

The PDS, which covers a total area of 62,500 hectares, is located in the south western part of Kaeng Krachan District, Phetchaburi Province, situated $99^{\circ} 20^{\prime} \mathrm{E}$ to $99^{\circ} 37^{\prime} \mathrm{E}$ latitude, and $12^{\circ} 33^{\prime} \mathrm{N}$ to $12^{\circ} 45^{\prime}$ $\mathrm{N}$. The western boundary of the PDS borders between the Kingdom of Thailand and the Republic of the Union of Myanmar by the Tenasserim Range, which runs in a north and south direction. Physically, it is a region of foothills of $140 \mathrm{~m}$ AMSL, surrounded by mountains, with river plains in the center.

Most areas in the PDS are sloping lands, with an average gradient of more than $35 \%$ falling to the river lowlands of Pranburi (Figure 1), which is occupied by communities. In addition, the plain area of the PDS covers only $15 \%$ of the total area.

Most parts of the PDS are tropical rain forest ecosystems of KKNP, which are a watershed of natural water courses. In the west of the PDS, most of the natural water courses are arbitraries of the Pranburi River, which is the main river formed from the joining of four headstreams (Huay Sat Lek, Huay Sat Yai, Huay Hang, and Huay Sok) and feed the communities in the lowlands. A small canal, Huay Pa Dang, is another natural water course in the subdistrict, and feeds runoff to the Huay Pa Dang Reservoir, which is a water supply during the dry season. Agriculture on the lowlands of the PDS, in the forms of monocropping and livestock farming, is the main occupation of the majority of the population [24], with the population growth rate increasing continuously, $2.80 \%[24,25]$.

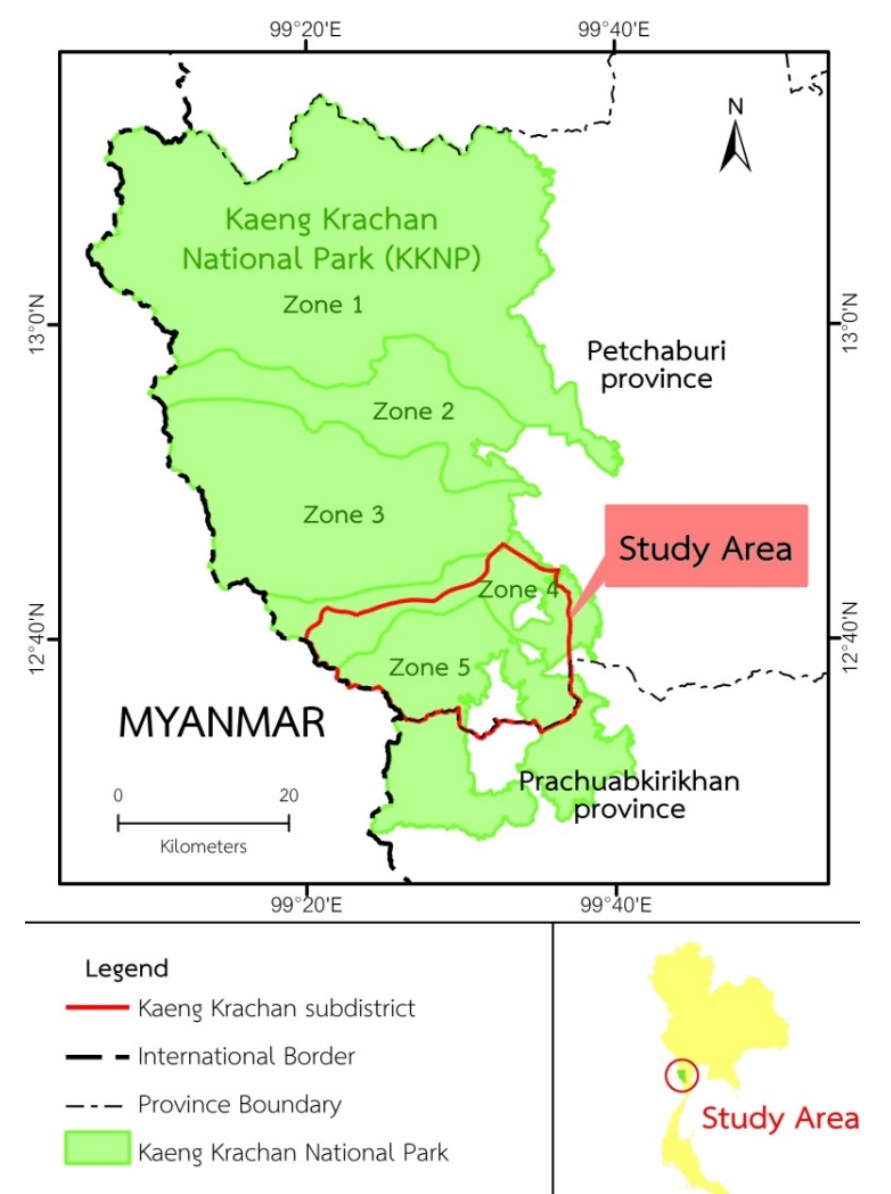

Figure 1 Topographic information of the PDS, covering 62,500 hectares, and of KKNP-zone five 


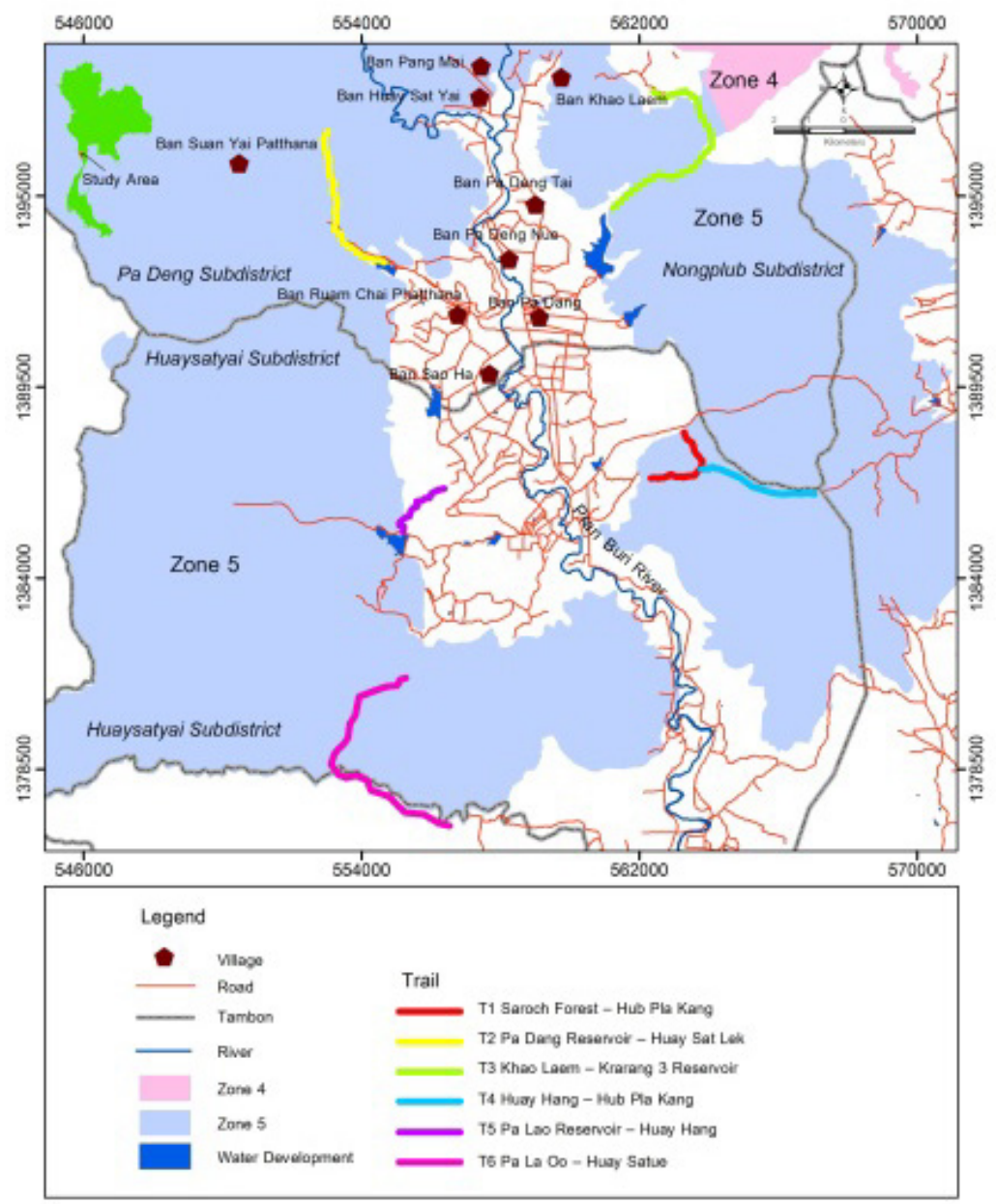

Figure 2 Rapid rural appraisal base map demonstrating interrelationship of community settlement and wild Asian elephants from KKNP

\section{Community attitudes to elephant dispersal in the PDS}

All ten village chiefs of the PDS were selected for their perceptions and attitudes on the elephant dispersal to their agricultural lands, and their suggestions for using community-based natural resource management. The information of local attitudes was used to explain local participation in conservation management to increase a positive interrelationship between the villagers and the wild elephants. The social views, including beliefs, feelings, and actions related to the elephants, were recorded by adapting some procedures for attitude assessment from the Rapid Rural Appraisal (RRA) to obtain new information and to formulate new hypotheses [26] about natural resource management for elephant conservation (Figure 2). Unstructured research methods, including field observation studies and in-depth interviews of community leaders, were planned. The chiefs of ten villages were chosen depending on their position of person's trait value in participation for supporting decisions towards the improvement of conservation management.

\section{Determination of human-dimension aspect on wild Asian elephant disturbance}

The human-dimension aspect included water development and food and cover production in the areas of the PDS. Patterns of vegetation cover and natural water availability that have significant effects 
http://wjst.wu.ac.th

on elephant habitats were focused on dating from 1975, 1992, 2002, and 2011. The presence of water and vegetation cover is vital for increasing wildlife population and expanding feeding [2]. However, generally, wildlife habitat improvement in developing countries are retarded by factors related to anthropogenic disturbance, and are a complex dynamic of problems occurring in both spatial and temporal dimensions [26-28]. Procedures of land cover determination regarding elephant dispersal to the agricultural areas were conducted using satellite image data collection, satellite image interpretation, field survey, and accuracy assessment of land use cover [29-31].

1) Gathering data: Satellite images of KKNP and the PDS were acquired for later determination of land use cover change: in 1975 by Aerial photograph, satellite images taken using Landsat-5 TM in 1992, and using Landsat-7 in 2002. Information on the studied areas was also depicted by using the 1:50,000 topographic maps of Thailand (AMS L708), and satellite data from Google Earth provided by Google Inc were also collected.

2) Interpretation of satellite images: The image classification techniques by ENVI version 5.4 from Flexera Software to interpret the obtained Landsat-5 TM images, with a ground resolution of $30 \mathrm{~m}$ covering the land cover types of the PDS and KKNP areas, were conducted using the supervised and unsupervised classification methods.

3) Field survey: A field survey was performed to check the accuracy of the classified land use types by randomly selecting sets of total points, where a GPS tracking unit using GPS tracking software (GAMIN 60Cx) was used to position the forest, agriculture, community, and water body areas, as well as for delineating line-spots where elephants, or their evidence, such as trail footprints, dung, or feeding signs, were found.

4) Accuracy assessment of land use land cover classification: the accuracy of the land use types was ascertained using ground truth points collected from the study area, and training sites were generated for each type of land use in the study area.

\section{Elephant dispersal}

1) Information on environmental factors and elephant trails delineating from found elephants, or their evidence, such as trails footprints, dung and feeding signs, were conducted in zone 5 of KKNP using line transect methods during the dry and wet seasons from September, 2015 to November, 2015.

2) The collected data of elephant dispersal trails located on the land use cover maps were compiled with the GPS data and modified into spatial data models overlaid with the environmental factors; vegetation, forest type, height, slope, water resources, salt lick sites, roads, and protected forest management units. In addition, the data of wild elephants derived from KKNP patrol observations were used as supporting data for studying the distribution of wild elephants.

\section{Results and discussion}

Local attitudes of villagers in the PDS related to elephants in KKNP

Attitudes and roles of the village chiefs of ten communities located in the PDS were recorded by using the participatory approach, the RRA in understanding the current situations of wild elephant dispersal to their agricultural lands, and ways forward to managing these problems using communitybased natural resource management for land use management of the PDS area interrelating to KKNP conservation. The results revealed their settlement since 1975, their experience in crop damage by elephants, and their crop protection measures.

Local people settled in the PDS from 1975 by being laborers in the lumber industry during the forest concession. To improve the formal access to land and tenure policy in 1977, three years before the establishment of KKNP in 1981, land allocation of 3.52 hectares was permitted to the settlers by them receiving a piece of 0.32 hectares of homestead near the Pranburi River, and then another 3.20 hectares of irrigated agricultural lands next to the KKNP boundary with water reservoirs. In 2014, the population increased to 6,461 people, with 2,410 households distributed in ten villages of the PDS. Results from the in-depth interviews showed that the settlers, especially in four villages with water reservoirs adjacent to the KKNP boundary, have experienced crop damage by small groups of 3 - 5 elephants from KKNP 
http://wjst.wu.ac.th

(Table 1) since 1992. The chiefs of the affected villages revealed that their lands were often damaged by elephants from KKNP during the dry seasons in November to April every year from the need for water. The elephants were found wandering the Pranburi River and major reservoirs during the dry period. They were found at night from 8 p.m. to 2 a.m., with the duration of incidence took only an hour; they then left for KKNP. The adverse impact on crop damages depended on immediate response, e.g., alarm systems and night response team coordination combining to discourage elephants to leave crop lands. The continued negative attitudes of communities towards the adverse impact was negative acceptance.

Table 1 Villages and their populations in the PDS in 2014 and their experience of crop damage by wild Asian elephants from KKNP in 2015

\begin{tabular}{|c|c|c|c|c|c|c|}
\hline \multirow{2}{*}{ No. } & \multirow{2}{*}{ Villages } & \multirow{2}{*}{$\begin{array}{c}\text { Affected } \\
\text { Households in } \\
2015^{* * *}(\%)\end{array}$} & \multirow{2}{*}{$\begin{array}{l}\text { Household } \\
\text { in } 2014^{*}\end{array}$} & \multicolumn{3}{|c|}{ Population in $2014^{*}$} \\
\hline & & & & Male & Female & Total \\
\hline 1 & Ban Pa Deng Nue & 5 & 239 & 196 & 169 & 365 \\
\hline 2 & Ban Ruam Chai Phatthana & 100 & 359 & 390 & 365 & 755 \\
\hline 3 & Ban Pa Dang & 100 & 321 & 358 & 356 & 714 \\
\hline 4 & Ban Sao Ha & 101 & 177 & 251 & 230 & 481 \\
\hline 5 & Ban Suan Yai Patthana & 100 & 152 & 158 & 145 & 303 \\
\hline 6 & Ban Pa Deng Tai & 50 & 348 & 1174 & 1089 & 2263 \\
\hline 7 & Ban Huay Sat Yai & 100 & 150 & 140 & 132 & 272 \\
\hline 8 & Ban Khao Laem & 10 & 253 & 253 & 223 & 476 \\
\hline 9 & Ban Pang Mai & 10 & 202 & 224 & 228 & 452 \\
\hline 10 & Ban Pa Mark-Prupu & None & 209 & 196 & 184 & 380 \\
\hline \multicolumn{3}{|c|}{ Total } & & 3,340 & 3,121 & 6,461 \\
\hline
\end{tabular}

Source: *Households and population was retrieved from the Department of Provincial Administration in 2014.

**Households in the villages which experienced crop damage, collected from in-depth interviews conducted in 2015.

Table 2 Relative change classification for land use tover types of the PDS studied in 1975, 1992, 2002, and 2011

\begin{tabular}{lrrrrrrrr}
\hline \multirow{2}{*}{ Land use type } & \multicolumn{7}{c}{ Relative change in land area (ha) } \\
\cline { 2 - 9 } & \multicolumn{1}{c}{$\mathbf{1 9 7 5}$} & $\mathbf{( \% )}$ & \multicolumn{1}{c}{$\mathbf{1 9 9 2}$} & $\mathbf{( \% )}$ & $\mathbf{2 0 0 2}$ & $\mathbf{( \% )}$ & $\mathbf{2 0 1 1}$ & $\mathbf{( \% )}$ \\
\hline Forest & $41,624.71$ & 99.62 & $35,392.14$ & 84.71 & $36,851.19$ & 88.20 & $38,131.94$ & 91.27 \\
Agricultural area & - & - & $1,999.38$ & 4.79 & $2,777.62$ & 6.65 & $2,158.63$ & 5.17 \\
Residential area & - & - & 684.09 & 1.64 & 704.03 & 1.69 & 911.05 & 2.18 \\
Bare land & 152.62 & 0.37 & $3,627.75$ & 8.68 & $1,369.15$ & 3.28 & 536.04 & 1.28 \\
Water body & 4.65 & 0.01 & 78.62 & 0.18 & 79.99 & 0.18 & 44.32 & 0.10 \\
Total & $41,781.98$ & 100.00 & $41,781.98$ & 100.00 & $41,781.98$ & 100.00 & $41,781.98$ & 100.00 \\
\hline
\end{tabular}


http://wjst.wu.ac.th

The villagers believed that this problem needed practical management regarding the agricultural land expansion to the KKNP border and the increase of elephant numbers. Local mitigation measures for less damage was to sanction the cultivation practices of crops of maize, pineapple, fruit trees, and vegetables into undamaged replacement, such as dairy farming, fends, or wire barriers. They believed that elephants could learn the barriers, and eventually cross the water courses during dry season again. Therefore, information of local attitudes should lead to more understanding of Asian elephant behavior and encourage local participation in conservation management to increase a positive interrelationship between the villagers and the wild elephants [32]. Regarding managing these problems using communitybased natural resource management for the land use management of the PDS area integrated with KKNP conservation, the land use cover changes around the areas at the border of KKNP, which may have significant effects on elephant habitat improvement due to human activities, have been identified as the major challenges or opportunities for sustainable biodiversity management [32-36].

\section{Human-dimension on wild Asian elephant disturbance}

Access of land space and natural resources, including water availability, are competitive interrelationships between human and wildlife [37,38], and this is particularly true of large mammals. Human-elephant conflict (HEC) in the studied areas have been established from crop raiding and local commutation disturbance. HEC has had obvious significant impact as the local population in the PDS rapidly increased, and crop cultivation encroached the elephant habitat $[39,40]$ especially water courses in the lowland adjacent to the Pranburi River.

Prior to 1990, wild Asian elephants followed seasonal migration trails from the middle of KKNP (Khao Sam Yod Forest) to Huay Sok, Hub Tao Valley, Huay Khrai Forest, and Huay Phueng Forest in the south during the dry season, and then went back to the middle of the park during the rainy season. However, after 1991, the elephants' trails were encroached by crop expansion and human settlements. The route interruption seriously expanded to the border of KKNP, consequently separating KKNP into two forest patches. The establishment of villages, specifically in the north, the east and the west of the Pranburi River, obviously occurring on the right side of the Pranburi River, barricaded the elephants from the main forest accessing the river. In particular, Ban Huay Sok village was established in the way of the main seasonal migration route that wild elephants previously used to move up to the forest in the north. The wild elephants were then obstructed and pressured to survive in Pa-La-U forest, an area of about 25,000 hectares, since they were unable to move up to the north and the west.

The serious circumstance of HEC was addressed in some areas adjacent to the KKNP border through crop damage incidences, especially during the dry season. In 1992, twenty-two elephants patrolled from KKNP to the river and reservoirs, and damaged plantation and crops such as pineapple, banana, mango, and lime in the PDS. They invaded pineapple farms at Ban Chaloem Phra Kiat Pattana in April in the same year, and one of them was killed by villagers. In 1993, thirty-eight elephants invaded 96 hectares of pineapple plantation at Ban Thung Kra Thing village, and eventually one elephant was found killed at Huay Pla Kang Valley, and another one at Ban Huay Sok village. The incidents of HEC are still increasing. After 2013, incidents of elephants being killed for ivory, and their babies being killed by electric fences nearby the PDS, were reported.

Changes in land use in the $\mathrm{Pa}$ Deng subdistrict, particularly in the central area that includes the traditional elephants' migration routes from the east to the west of KKNP in the KKFC, caused conflict between villagers and elephants. From satellite images taken in 1975, 1992, 2002, and 2011, the land use in the study area could be classified into five types, including Forest, Agricultural area, Residential area, Bare land, and water course (Table 2). In 1975, the area of the PDS was natural forest, but less than 0.5 $\%$ was bare land, which was vegetation cover and water courses. However, the evidence of human encroachment into the elephant habitat has adverse impacts on both human and elephant interrelationships. After the KKNP establishment in 1981, the forest size was stable, but other land use types, especially bare land and natural water courses, which were elephant feeding areas were replaced by agricultural and residential lands in the south/west direction, consequently interrupted the east/west seasonal migration of elephants from KKNP. This replacement of human disturbance expanded to the border of KKNP and diminished the bare lands (Figure 3). 

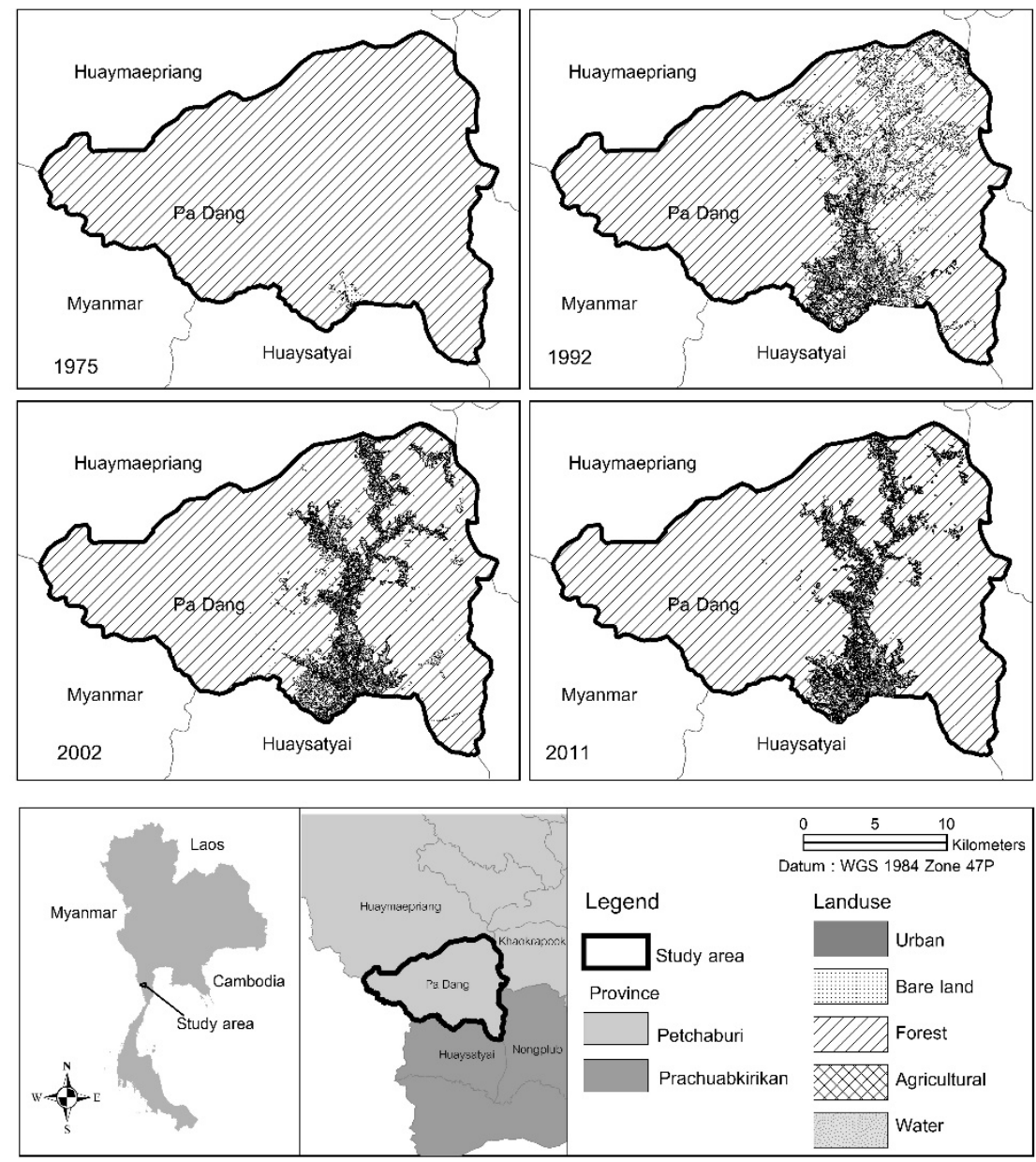

Figure 3 Land use cover types depicting the changes of patterns that disturbed the seasonal migration of elephants in KKNP in 1975, 1992, 2002, and 2011

Evidence of human disturbance was shown by 1992 , with the $6.43 \%$ of agricultural and residential areas, and the largest area being forest $(84.71 \%$ of the total area), followed by bare land $(8.68 \%)$, agricultural $(4.79 \%)$, community $(1.64 \%)$ and water body $(0.18 \%)$. In 2011 , evidence of HEC was obviously significant and had become a political problem, but the size of forest and the agricultural and residential areas were slightly increased, covering 91.26 and $7.38 \%$, respectively, while the bare land and water course depleted to only $1.38 \%$.

Thus, for the change in land use from 1975, 1992, 2002, and 2011, the depletion of KKNP may not be a significant factor for elephant dispersal, but the development of human practices at the middle of zone 5 of KKNP occupying the bare land and water courses, which were elephant feeding areas, should be further discussed by using spatial analysis of the land use changes in the PDS.

Results of spatial analysis of the land use changes in the PDS between 1992 and 2011, the period of found significant impacts on HEC, are shown in Table 3 and are summarized as follows:

- Residential area expansion: from the community area in 1992, $24.97 \%$ still remained as a community area in 2011 , while $34.59,28.70,11.30$, and $0.44 \%$ had become agricultural, forest, bare land, and water body areas, respectively. 
http://wjst.wu.ac.th

- Crop cultivation expansion: from the agriculture area in 1992, $31.06 \%$ still remained as an agricultural area in 2011, while 15.87, 42.23, 10.80, 17.99, and $0.04 \%$ had become community, forest, bare land, and water body areas, respectively.

- Minor changes of Zone 5 of KKNP in the PDS: from the forest area in 1992, 98.86\% still remained as a forest area in 2011, while $0.216,0.75,0.18$, and $0.005 \%$ had become community, agricultural, bare land, and water body areas, respectively.

- Rapid conversion of bare land to human practice cultivation: from the bare land in 1992, only $4.74 \%$ still remained as bare land in 2011 , with $9.59,28.08,57.55$, and $0.05 \%$ converted to community, agricultural, forest, and water body areas, respectively.

- Hasty depletion of natural water course in the lowland of PDS: from the water body in 1992, $47.59 \%$ was still a water body in 2011 , while $0.25,23.39,18.08$, and $10.68 \%$ had changed into community, agricultural, forest, and bare land areas, respectively.

It is can be concluded that the significant factor affecting elephant dispersal and encouraging HEC is the conversion of land use cover in the area of elephant feeding. Moreover, the depletion of available natural water courses, including access to the Pranburi River and other man-made reservoirs, may enhance crop damages in the village areas adjacent to the water courses. Ban Ruam Chai Phatthana, Ban Pa Dang, Ban Suan Yai Patthana, and Ban Huay Sat Yai were four villages located adjacent to man-made reservoirs.

Table 3 Cover area conversion of land use types found in the PDS during 1992 to 2011

\begin{tabular}{ccccccc}
\hline \multirow{2}{*}{ Land use type } & \multicolumn{5}{c}{ Land use area (ha) } \\
\cline { 2 - 7 } & $\mathbf{1 9 9 2}$ & \multicolumn{5}{c}{$\mathbf{2 0 1 1}$} \\
\cline { 2 - 7 } & & Community & Agriculture & Forest & Bare land & Water body \\
\hline Community & 684.09 & 170.92 & 236.85 & 196.41 & 77.34 & 2.57 \\
Agricultural & $1,999.38$ & 317.25 & 621.00 & 844.31 & 215.95 & 0.87 \\
Forest & $35,392.1$ & 74.90 & 263.82 & $34,989.28$ & 62.54 & 1.61 \\
Bare land & $3,627.75$ & 347.79 & $1,018.57$ & $2,087.73$ & 171.80 & 1.86 \\
Water body & 78.61 & 0.20 & 18.39 & 14.22 & 8.40 & 37.41 \\
\hline
\end{tabular}

Table 4 Indirect evidence of elephants in six trails found in Zone 5 of KKNP in KKFC

\begin{tabular}{lccccc}
\hline \multirow{2}{*}{ Elephant Trail } & Distance & \multicolumn{4}{c}{ Indirect evidence of elephants } \\
\cline { 3 - 6 } & $(\mathbf{k m )}$ & Dung & Footprint & Feeding & Direct sight \\
\hline 1. Saroch Forest - Hub Pla Kang & 2.86 & 10 & 4 & 3 & - \\
2. Pa Deng Reservoir - Huay Sat Lek & 5.02 & 15 & 5 & 10 & - \\
3. Khao Laem - Krarang 3 Reservoir & 6.39 & 12 & 4 & 5 & (Sound) \\
4. Huay Hang - Hub Pla Kang & 3.48 & 10 & 6 & 4 & - \\
5. Pa Lao Reservoir - Huay Hang & 2.19 & 8 & 2 & 6 & - \\
6. Pa La Oo - Huay Satue & 7.82 & 15 & 5 & 4 & - \\
\hline Total & 27.76 & 70 & 26 & 27 & \\
\hline
\end{tabular}


http://wjst.wu.ac.th

\section{Dispersal of wild Asian elephants in KKNP related to human practices in the PDS}

According to numbers of elephants in KKNP done by the collaboration of the Department of National Parks, Wildlife and Plant Conservation (DNP) and the Wildlife Conservation Society (WCS) Thailand program in 2013, there were two groups of wild elephants in the study area. The first group lived upstream of the Phetchaburi River, down to Ban Krang and Huay Komkrit, and consisted of 130 elephants. The same numbers of 130 elephants were recorded living in Pa Deng, Huay Sat Yai, Nong Plub, and $\mathrm{Pa}$ La Oo subdistricts (Figure 4).

In 2015, the results of the field study of elephant dispersal behavior showed that there were six significant trails, and their directions converged toward nearby watering places (Figure 5). The total distance of six trails was $27.76 \mathrm{~km}$, aligned in the area of the PDS, parts of KKNP, and Huay Sat Yai subdistrict in Zone 5 of KKNP. Direct and indirect evidence of wild elephants were observed and collected from all six trails: indirect evidence of a total of 70 dung piles, 27 feeding signs, and 26 footprints were found during the field survey, but sound from elephants was heard only in trail 3 (Table 4). Water supply is common ground information that controls the relationship between biodiversity development and the management of ecosystem services and is an important factor in conservation. Water availability for wild animals should be retained in the forest habitat throughout the dry season [4].

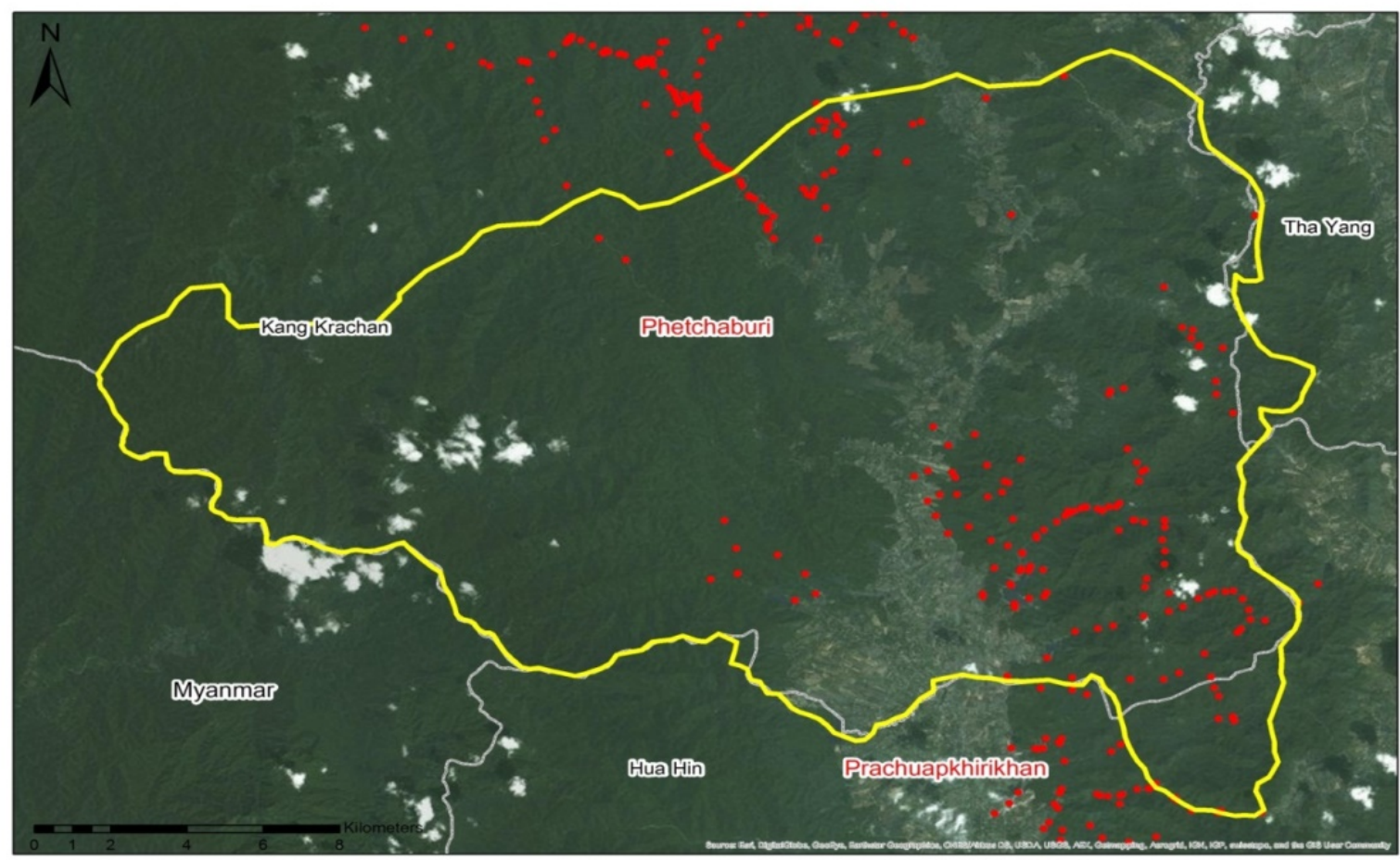

Figure 4 Distribution of wild Asian elephants in KKNP and nearby areas 

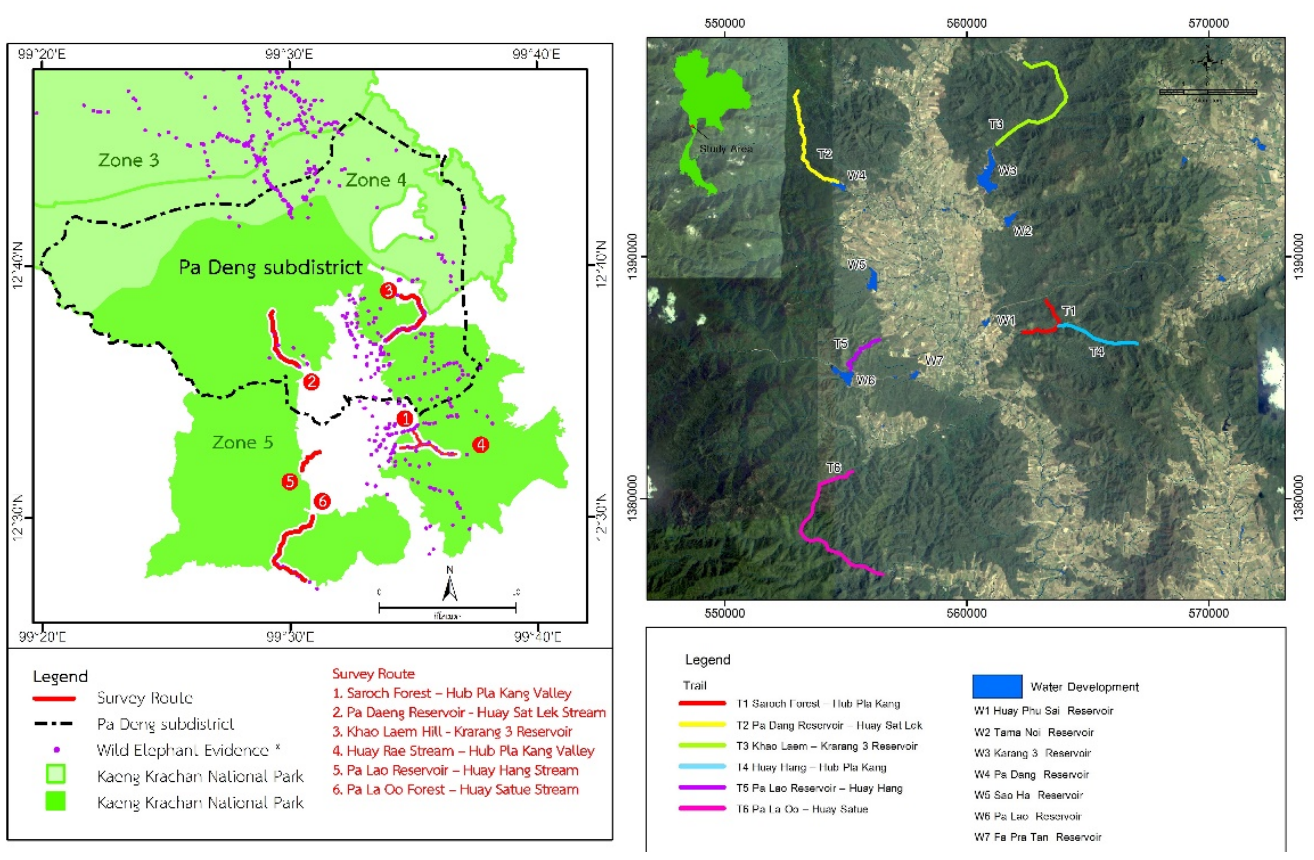

Figure 5 locations of close proximity to available water supplies related to six elephant trails found at border of zone 5 of KKNP

\section{Conclusion and recommendations}

The villagers in the PDS believed that the problem of HEC in KKNP needed practical management on the growth of agricultural lands expanding to the KKNP border and measures on the increasing elephant numbers. Changes in land use in the PDS, particularly in the central area which was the traditional elephants' migration route, caused the conflict between villagers and elephants. To reduce the impact of HEC, crop cultivation such as maize, pineapple, fruit trees, and vegetables should be replaced with undamaged replacement, such as dairy farming, fend, or wire barriers. They shared their experiences of elephant behaviors and learning ability bringing about the failure of water trenches leading to more understanding of elephant behavior and encouraging local participation in natural resource conservation. This community-based natural resource management in both the replacement of less damaging agricultural practices and measures on elephant increasing numbers and fencing should be integrated to KKNP conservation. Regarding land allocation in the past and the growth of community resettlement consequently separating KKNP into two forest patches, the significant factor affecting elephant dispersal and encouraging HEC is the conversion of land use cover in the area of elephant feeding. Moreover, the depletion of available natural water courses, including access to the Pranburi River and other man-made reservoirs, may enhance crop damage to adjacent areas to water courses. The development of human practices should be further discussed, and the human-elephant interrelationship must be quantified and hypothesized regarding community responses and local community-based natural resource management. 
http://wjst.wu.ac.th

\section{Acknowledgements}

This research was financially supported by the Graduate School of Chulalongkorn University. We thank officers of Kaeng Krachan National Park for providing access to the studied sites in the park, officers of the Wildlife Conservation Society, the villagers and local leaders in the PDS for their help in the field survey and data records, and Dr. Kallaya Suntornvongsagul from the Environmental Research Institute for carrying out the complete paper.

\section{References}

[1] R Cline, N Sexton and SC Stewart. A Human-dimensions Review of Human-wildlife Disturbance: A Literature Review of Impacts, Frameworks, and Management Solutions. U.S. Geological Survey. Open-File Report, 2007, p. 88.

[2] J Yoakum,WP Dasmann, HR Sanderson, CM Nixon and HS Crawford. Habitat Improvement Techniques. In: SD Schemnitz (Ed.). Wildlife Management Techniques Manual. $4^{\text {th }}$ ed. The Wildlife Society, Washington DC, 1980, p. 330-402.

[3] RM Laws. Elephants as agents of habitat and landscape change in East Africa. Oikos 1970; 21, 115 .

[4] J Botha, ETF Witkowski and CM Shackleton. A comparison of anthropogenic and elephant disturbance on Acacia xanthophloea (fever tree) populations in the Lowveld, South Africa. Koedoe 2002; 1, 9-18.

[5] AC Gupta. Elephants, safety nets and agrarian culture: Understanding human-wildlife conflict and rural livelihoods around Chobe National Park, Botswana. J. Pol. Ecol. 2013; 20, 238-54.

[6] DM Lewis. Distribution effects on elephant feeding: evidence for compression in Luangwa Valley, Zambia. Afr. J. Ecol. 1986; 24, 227-41.

[7] Wildlife Conservation Society. Annual Report 2014. Available at: http://fscdn.wcs.org/2015/07/24/smu9vd9uy_2014_WCS_Annual_Report.pdf, accessed May 2015.

[8] E Rood, AG Abdullah and V Nijman. Using presence-only modelling to predict Asian elephant habitat use in a tropical forest landscape: implications for conservation. Divers. Distrib. 2010; 16, 975-84.

[9] MA Kumar and M Singh. Behavior of Asian elephant (Elephas maximus) in a land-use mosaic: Implications for human-elephant coexistence in The Anamalai Hills, India. Wildl. Boil. Pract. 2010; 6, 69-80.

[10] Department of National Parks. Wildlife and Plant Conservation (DNP), Wildlife Research Division. Elephant in Thailand. 2009.

[11] RE Hoare. Determinants of human-elephant conflict in a land-use mosaic. J. Appl. Ecol. 1999; 36, 689-700.

[12] M Srikrachang and S Srikosamatara. Elephant crop raiding problems and their solutions at Kui Buri National Park, Southwestern Thailand. Natural History Bulletin of Siam Society. Nat. Hist. Bull. Siam Soc. 2005; 53, 87-9.

[13] B Noonto. An assessment of elephant in Thailand in nowadays. Available at: http://www.seub.or.th/ index.php?option=com_content\&view $=$ article\&id=1389:seubnews\&catid=5:2009-10-07-10-5820\&Itemid=14, accessed May 2017.

[14] BMAO Perera. The human-elephant conflict: A review of current status and mitigation methods. Gajaha 2009; 30, 41-52.

[15] R Zander. Thai Elephants on the Attack. Available at: http://siamandbeyond.com/thai-elephantsattack, accessed May 2017.

[16] SK Das and S Chattopadhyay. Human fatalities from wild elephant attacks: A study of fourteen cases. J. Forensic Leg. Med. 2011; 18, 154-7.

[17] A Okubo and SA Levin. The Basics of Diffusion. In: A Okubo and SA Levin (Eds.). Diffusion and Ecological Problems: Modern Perspectives. $2^{\text {nd }}$ ed. New York, 2000, p. 10-30.

[18] RH Yahner. Wildlife Behavior and Conservation. Springer-Verlag, New York, 2012, p. 174. 
http://wjst.wu.ac.th

[19] M Dupuis-Desormeaux, Z Davidson, L Pratt, M Mwololo and SE MacDonald. Testing the effects of perimeter fencing and elephant enclosures on lion predation patterns in a Kenyan wildlife conservancy. Peer J. 2016; 4, e1681.

[20] RWS Fynn, DJ Augustine, J David, MJS Peel, MD Garine-Wichatitsky. Review: Strategic management of livestock to improve biodiversity conservation in African savannahs: A conceptual basis for wildlife-livestock coexistence. J. Appl. Ecol. 2016; 53, 388-97.

[21] ML Merrison and HA Mathewson. Wildlife Habitat Conservation: Concepts, Challenges, and Solutions (Wildlife Management and Conservation). John Hopkins University Press, Maryland, p. 175.

[22] AT Vanak, M Thaker and R Slotow. Do fences create an edge-effect on the movement patterns of a highly mobile mega-herbivore? Biol Conserv. 2010; 143, 2631-7.

[23] MD Graham, I Douglas-Hamilton, WM Adams and PC Lee. The movement of African elephants in a human-dominated land-use mosaic. Anim. Conserv. 2009; 12, 445-55.

[24] S Wijitkosum, K Yolpramote and L Kroutnoi. Desertification risk assessment in Pa Deng subdistrict, adjoining area of Kaeng Krachan Natural Park, Thailand. In: Proceedings of the PSU Phuket International Conference. Price of Songkhanaklarin University, Phuket, Thailand. 2013, p. $10-2$.

[25] S Wijitkosum. Critical factors affecting the desertification in Pa Deng, Adjoining Area of Kaeng Krachan National Park, Thailand. EnvironmentAsia 2014; 7, 87-98.

[26] KS Freudenberge. Rapid Rural Appraisal and Participatory Rural Appraisal: A Manual for CRS Field Workers and Partners. Available at: http://www.crs.org/our-work-overseas/researchpublications/rapid-rural-appraisal-and-participatory-rural-appraisal, accessed May 2017.

[27] DJ Decker, SJ Riley and WF Siemer. Human Dimensions of Wildlife Management. The JohnHopkins University press, Baltimore, 2012, p. 279.

[28] JS Larson. Human Dimensions of Wildlife Management, Forests, Wildlife, and Habitat Management: A Critical Examination of Practice and Need. U. S. Forest Service Research Paper SE- 30, 1967, p. 27.

[29] JG Estes, N Othman, S Ismail, M Ancrenaz, B Goossens, LN Ambu, AB Estes and PA Palmiotto. Quantity and configuration of available elephant habitat and related conservation concerns in the lower kinabatangan floodplain of Sabah, Malaysia. Plos One 2012; 7, e44601.

[30] E Danquah. Spatial distribution of elephants versus human and ecological variables in Western Ghana. Adv. Ecol. 2016; 2016, 8038524.

[31] EO Ochieng. 2015, Characterizing the Spatial Distributions of Elephants in Mpala, Kenya. M.Sc. Dissertation. University of Twente, Enschede, Netherlands.

[32] Z Ma, B Li, W Li, N Han, J Chen and AR Watkinson. Conflicts between biodiversity conservation and development in a biosphere reserve. J. Appl. Ecol. 2009; 46, 527-35.

[33] JG Nelson and R Serafin. Assessing biodiversity: A human ecological approach. Ambio 1992; 21, 212-8.

[34] J Young, C Richards, A Fischer, L Halada, T Kull, A Kuzniar, U Tartes, Y Uzunov and A Watt. Conflicts between biodiversity conservation and human activities in the central and eastern European countries. Ambio 2007; 36, 545-50.

[35] M Tabarelli, LP Pinto, J SILVA, M Hirota and AL Bede. Challenges and opportunities for biodiversity conservation in the Brazilian Atlantic Forest. Conserv. Biol. 2005; 19, 695-700.

[36] AE Lugo. Management of tropical biodiversity. Ecol. Appl. 1995; 5, 956-61.

[37] SL Pimm, GJ Russell and JL Gittleman. The future of biodiversity. Science 1995; 269, 347-50.

[38] A Balmford, JL Moore, T Brooks, N Burgess, LA Hansen, P Williams and C Rahbek. Conservation conflicts across Africa. Science 2001; 291, 2616-26.

[39] HT Dublin, TO McShane and J Newby. Conserving Africa's Elephants: Current Issues and Priorities for Action. WWF, Gland, Switzerland, 1997.

[40] RE Hoare. Data Collection and Analysis Protocol for Human-Elephant Conflict Situations in Africa. IUCN African Elephant Specialist Group, Nairobi, Kenya, 1999, p. 41. 